\title{
An investigation on the supplementation of rosemary volatile oil to the laying quail diets
}

\author{
Gülay DENİ ${ }^{1, \mathrm{a}, \bigotimes}$, Mukaddes Merve EFİL ${ }^{1, \mathrm{~b}}$, Şerife Şule CENGİZ ${ }^{1, \mathrm{c}}$, Kerem ATAMAY ${ }^{1, \mathrm{~d}}$, \\ Bahadır ANAR ${ }^{1, e}$
}

\author{
${ }^{1}$ Uludağ University Faculty of Veterinary Medicine Department of Animal Nutrition and Nutritional Diseases, Bursa, TURKEY \\ aORCID: 0000-0003-3817-4359; ' ${ }^{\mathrm{O} O R C I D: ~ 0000-0003-0646-9777 ; ~ ' ~} \mathrm{ORCID:} \mathrm{0000-0003-0708-3833;}$

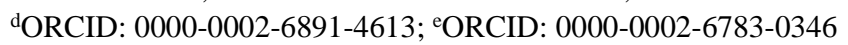

\author{
${ }^{\square}$ Corresponding author: denizg@uludag.edu.tr \\ Received date: 09.09.2020 - Accepted date: 10.02.2021
}

\begin{abstract}
The purpose of the current study was to detect the effects of different levels of rosemary volatile oil (VO) supplemented to laying quail diets on performance, egg quality parameters, and egg yolk oxidative stability. In this study, a total of 105 laying quails (Coturnix coturnix Pharaoh) at the age of 6 weeks were used and 3 main groups were formed, each containing 35 quails. Also, each main group was separated into 5 replicates containing an equal number of quails. Quails were fed a control diet without rosemary VO or diets which were containing at different levels (200 or $400 \mathrm{mg} / \mathrm{kg}$ ) of rosemary VO supplemented to the control diet. At the end of the study, which was continued for a total of 56 days, no significant difference was found in the feed intake, feed efficiency and egg weights among the control and experimental groups. The supplementation of rosemary VO at the levels of 200 and $400 \mathrm{mg} / \mathrm{kg}$ to the diets caused an increase in quails' egg production $(\mathrm{P}<0.01)$. However, there was no effect on the exterior and interior egg quality parameters. A significant decrease in malondialdehyde (MDA) levels in egg yolk were observed with both levels of rosemary VO at storage $(+40 \mathrm{C})$ for $7(\mathrm{P}<0.001)$ and $28(\mathrm{P}<0.01)$ days. Considering these data, it was concluded that rosemary VO can be supplemented to laying quail diets as a natural antioxidant without negatively affecting performance and egg quality parameters.

Keywords: Antioxidant, egg quality, laying quail, malondialdehyde, rosemary volatile oil.
\end{abstract}

\section{Biberiye uçucu yağının yumurtacı bıldırcın rasyonlarına ilave edilmesi üzerine bir araştırma}

Özet: Bu çalışmanın amacı, yumurtacı bıldırcın rasyonlarına farklı düzeylerde ilave edilen biberiye uçucu yağının performans, yumurta kalite parametreleri ve yumurta sarısının oksidatif stabilitesi üzerindeki etkilerini belirlemekti. Araştırmada, 6 haftalık toplam 105 yumurtacı bıldırcın (Coturnix coturnix Pharaoh) kullanılmış ve her biri 35 hayvan içeren 3 ana grup oluşturulmuştur. Ayrıca, her ana grup eşit sayıda bıldırcından oluşan 5 tekrar grubana ayrılmıştır. Bıldırcınlar, biberiye uçucu yağı içermeyen kontrol rasyonu veya kontrol rasyonuna ilaveten biberiye uçucu yağının farklı düzeylerini (200 veya $400 \mathrm{mg} / \mathrm{kg}$ ) içeren deneme rasyonları ile beslenmiştir. Toplam 56 gün sürdürülen araştırmanın sonunda, kontrol ve deneme gruplarının yem tüketimi, yemden yararlanma ve yumurta ağırlıklarında önemli bir fark bulunmamıştır. Biberiye uçucu yağının rasyona $200 \mathrm{ve} 400 \mathrm{mg} / \mathrm{kg}$ düzeylerinde ilave edildiği deneme gruplarının yumurta üretiminde artış $(\mathrm{P}<0,01)$ saptanmıştır. Yumurtaların buzdolabında depolanmasının $(+40 \mathrm{C}) 7$. $(\mathrm{P}<0,001)$ ve 28 . $(\mathrm{P}<0,01)$ günlerinde, biberiye uçucu yağının her iki dozu da yumurta sarısı malondialdehit seviyelerinde önemli bir düşüşe yol açmıştır. $\mathrm{Bu}$ veriler göz önüne alınarak; biberiye uçucu yağının bıldırcınların performans ve yumurta kalite parametrelerini olumsuz etkilemeksizin, rasyonlara doğal bir antioksidan olarak ilave edilebileceği sonucuna varılmıştır.

Anahtar sözcükler: Antioksidan, biberiye uçucu yağı, malondialdehit, yumurtacı bıldırcın, yumurta kalitesi.

\section{Introduction}

The ban on the supplementation of antibiotics to poultry feeds has inspired interest in natural feed additives such as probiotics, prebiotics, aromatic herbs and their essential oils which are not causing residue in animal products and resistance in microorganisms. The antimicrobial $(18,20,41,49)$, antioxidant $(10,35,51)$, antifungal $(33,39)$, antiparasitic $(44,45)$, antiviral (8), anti-inflammatory (1), hypolipidemic (54), immunostimulatory $(1,54)$, digestive system stimulator (46) and digestive enzyme activity enhancer (54) effects of herbal volatile oils are proved with many scientific studies. Rosemary (Rosmarinus officinalis L.), aromatic herb specific to the Mediterranean climate, is now widely grown all over the world. It is known as the herb with the highest antioxidant activity among aromatic herbs (19, 
38). This effect of rosemary is derived from the phenolic compounds, carnosic acid, carnosol, camphene, ursolic acid, rosmarinic acid, 1,8-cineole, $\alpha$ pinene and other $\mathrm{VO}$ components that give the herb its characteristic odour $(3$, 6, 48, 50). Viuda-Martos et al. (57) tested volatile oils obtained from five aromatic herbs (oregano, thyme, clove, sage and rosemary) commonly used in the Mediterranean diet for their antioxidant properties using different in vitro methods and concluded that rosemary VO has the highest iron-chelating ability.

Recently, there has been a strong debate about the safety aspects of chemical preservatives, as they are thought to be responsible for a number of residual toxicity, carcinogenic and teratogenic cases. Therefore, there has been a heavy demand for foods containing natural preservatives around the world. In line with this demand, the researchers focused on studies to determine the protective effect of natural additives, such as extracts from different herbs, to extend the shelf life of foods. Several studies have identified many beneficial effects of rosemary, including its potent antioxidant activity $(48,57)$ as well as antibacterial, anti-inflammatory and immunomodulatory effects $(15,23,24,60)$. Our hypothesis was that the strong antioxidant effect of rosemary VO would extend the shelf life of quail eggs and improve the quail's performance due to the general effects of herbal volatile oils (increasing the flavor of the feed and the activity of digestive enzymes, etc.). Thus, the purpose of the current study was to investigate the effects of different levels of rosemary $\mathrm{VO}$ on performance, exteriorinterior egg quality parameters in laying quails and also to prove the antioxidant activity by determining the effect on the oxidative stability of the eggs.

\section{Materials and Methods}

Quails, housing and management: This research was conducted within the framework of the rules determined by the Uludağ University Ethical Committee (decision no. 2018-15/04). In this study, a total of 105 quails (Coturnix coturnix Pharaoh) at the age of 6 weeks were used and 3 main groups were constituted, each containing 35 quails. Also, in order to compare the feed intake and feed efficiency parameters of the experimental groups, each main group was divided into 5 replicates containing 7 quails. The quails were placed in cages at $112.5 \mathrm{~cm} 2$ per quail and kept there until the end of the study. Feed and water were provided ad libitum to quails. They were exposed to $16 \mathrm{~h}$ of light and $8 \mathrm{~h}$ of darkness a day. Average ambient temperature was $22{ }^{\circ} \mathrm{C}$ and the relative air humidity was $65 \%$. The study was continued for 56 days.

Experimental diets and measurements: The quails were fed a corn and soy-based basal diet formulated to meet the NRC nutrient requirements of the laying quails
(42). The diet did not contain any antioxidant other than a basic level of vitamin E (Table 3). Quails were fed a control diet without rosemary $\mathrm{VO}$ or diets containing rosemary VO at levels of $200 \mathrm{mg} / \mathrm{kg}$ (Group 1) or 400 $\mathrm{mg} / \mathrm{kg}$ (Group 2) in addition to the control diet. While deciding on the levels of rosemary VO supplemented to the treatment group, the information in the literature (22, 59) were taken into consideration. The specific gravity value of rosemary VO was detected by the supplier company (Semi Etheric Oil Ind.trade.co.ltd., Mersin /Turkey). This value were considered for calculating the amount of rosemary VO to add to the diets. The nutrient composition of the basal diet was detected according to AOAC procedures (4). Spectrophotometric determinations of calcium and total phosphorus were made according to the methods of Farese et al. (21) and, Gericke and Kurmies (26), respectively. Carpenter and Clegg equation (14) was used to calculate the metabolizable energy level: $\mathrm{ME}, \mathrm{kcal} / \mathrm{kg}=53+38[(\mathrm{CP}$, $\%)+(2.25 \times$ ether extract, $\%)+(1.1 \times$ starch, $\%)+($ sugar, $\%)]$.

Performance, exterior and interior egg quality: Eggs were picked up and recorded each day, and the egg production percentage was calculated on a replicate basis. Every 2 weeks, feed intake (g/quail/day) was determined by weighing the remaining feeds from replicates. Also, all eggs collected from replicates were weighed separately to determine egg weight and averaged. Feed efficiency was calculated as consumed $\mathrm{kg}$ feed per $\mathrm{kg}$ egg and for a dozen eggs. Fifteen eggs from each main group (3 eggs from per replication group) were randomly taken to detect egg quality parameters every 2 weeks. Eggshell thickness was measured using an eggshell thickness gauge (Orka Technology Ltd, USA) from the top, middle and bottom parts of the eggshell after the shell membrane was removed. Eggshell breaking strength was detected with a cantilever system (5) and the values were recorded in Newton (N) unit. The heights of the albumen were measured in the egg samples, and then the haugh units belong to all groups were calculated by placing these values in the formula (13).

Measuring of chemical composition of the rosemary VO: The pure rosemary VO (Origin; Mersin /Turkey, Extraction Type; Hydro distillation, Density; 0.895 at $20^{\circ} \mathrm{C}$ ) used in this study were obtained from Semi Etheric Oil Industry and Trade Limited Company. Gas chromatography analysis of rosemary VO was carried out on an MS-Thermo Polaris Q GC-Thermo Trace GC (Thermo Ficher inc, MA, USA) ultra-fitted with a fused HP5-MS capillary column (Thermo Ficher inc, MA, USA) ( $30 \times 0.25 \times$ film thickness $0.5 \mu \mathrm{m})$. The temperature was programmed to rise from $95{ }^{\circ} \mathrm{C}$ to $240{ }^{\circ} \mathrm{C}$ at $4{ }^{\circ} \mathrm{C} / \mathrm{min}$. Samples were injected in split mode at $250^{\circ} \mathrm{C}$. Helium gas was used as the carrier at a pressure of 1.3610 atm. 
Determination was made with FID $\left(250{ }^{\circ} \mathrm{C}\right)$ and the injection volume was the same for all samples $(8.1 \mu \mathrm{l})$. Chromatograms were detected using MS or MS/MS. Internal standards were taken into account in the calculation of data (43).

Thiobarbituric acid (TBA) analysis of egg yolk: At the end of this study, 45 egg yolk samples (15 from each main group) were measured for MDA levels. The lipid oxidation value of egg yolk samples stored at $4{ }^{\circ} \mathrm{C}$ in the refrigerator was determined on 1, 7 and 28 days. MDA levels in eggs from experimental groups were measured as a secondary oxidation product according to the TBA method which is a spectrophotometric method defined by Ke et al. (34). A modification of the 2-thiobarbituric acid method was used, and the results were expressed as the amount of 2-thiobarbituric acid reactive substances (mg MDA). This method is based on the observation of a red colour that is created by the oxidation of unsaturated fatty acids with TBA after heating MDA.

Statistical analysis: Statistical analysis was performed using the Statistical Package for the Social Sciences version 22.0 (SPSS, Chicago, IL, USA). One way ANOVA was used to evaluate the effects of rosemary VO on the performance parameters (egg weight, egg production, feed intake, feed efficiency), egg quality (shape index, eggshell thickness, eggshell breaking strength, haugh unit, yolk color) and egg oxidative stability (MDA levels). Values were expressed as arithmetic means \pm standard error of the mean (SEM). Tukey test was used as a post hoc test and the level of significance used in all of the tests was $\mathrm{P}<0.05$ (55).

\section{Results}

In the study, the analysed VO components of rosemary supplemented to the quail diets are shown in Table 1. As can be seen from the table, the main active ingredients of rosemary VO were 1,8-cineol (43.96\%), $\alpha$ pinene $(25.33 \%)$, camphene $(11.09 \%)$ and 3 -carene $(10,7$ $\%)$, respectively. Specific gravity value and levels of rosemary VO are summarised in Table 2. The specific gravity value of rosemary $\mathrm{VO}$ was $0.895 \mathrm{~g} / \mathrm{mL}$. The amounts of rosemary VO supplemented to the quail diets were calculated according to the specific gravity value of the VO. Ingredients and nutrient composition of the basal diet are given in Table 3. The analyzed dry matter, ether extract, ash, total phosphorus, calcium values and the calculated metabolizable energy value of the basal diet was within the normal range for laying quails reported by NRC (42). In this study, no significant difference was found on the feed intake, feed efficiency and egg weights among the control and experimental groups. The supplementation of rosemary VO at the levels of 200 and $400 \mathrm{mg} / \mathrm{kg}$ to the diets caused an increase in quails' egg production $(\mathrm{P}<0.01)$. However, there was no effect on the
Table 1. Analysed chemical composition of rosemary VO.

\begin{tabular}{|c|c|}
\hline \multicolumn{2}{|c|}{ Rosemary $\mathrm{VO}$} \\
\hline Components & $(\%)$ \\
\hline 1,8-cineole (Eucalyptol) & 43.96 \\
\hline$\alpha$-Pinene & 25.33 \\
\hline Camphene & 11.09 \\
\hline 3-carene & 10.70 \\
\hline D-limonene & 2.5 \\
\hline Limonene & 1.77 \\
\hline Ocimen & 1.68 \\
\hline$\beta$-pinene & 1.40 \\
\hline Camphor & 0.73 \\
\hline Bornyl acetate & 0.04 \\
\hline Borneol & 0.03 \\
\hline Isoborneol & 0.02 \\
\hline Caryophyllene & 0.02 \\
\hline
\end{tabular}

Table 2. Specific gravity value and amounts of rosemary VO supplemented to quail diets.

\begin{tabular}{lccc}
\hline $\begin{array}{l}\text { Specific } \\
\text { Gravity* }\end{array}$ & Control & Group1 & Group2 \\
\hline & - & $200 \mathrm{mg} / \mathrm{kg}$ & $400 \mathrm{mg} / \mathrm{kg}$ \\
\cline { 2 - 4 } $0.895 \mathrm{~g} / \mathrm{mL}$ & - & $0.22 \mathrm{ml}$ & $0.44 \mathrm{ml}$ \\
\hline
\end{tabular}

*The amounts of rosemary VO supplemented to the treatment diets were calculated using the specific gravity value of VO.

Table 3. Ingredients and nutrient composition of the basal diet (as fed basis).

\begin{tabular}{|c|c|}
\hline \multicolumn{2}{|l|}{ Ingredients, \% } \\
\hline Corn & 45.00 \\
\hline Soybean Meal & 23.15 \\
\hline Full Fat Soybean Meal & 13.00 \\
\hline Wheat & 4.00 \\
\hline Sunflower Meal & 3.00 \\
\hline Vegetable Oil & 3.80 \\
\hline Calcium Carbonate & 6.40 \\
\hline Dicalcium Phosphate & 1.00 \\
\hline $\mathrm{NaCl}$ & 0.30 \\
\hline DL-Methionine & 0.10 \\
\hline Vitamin-Mineral Premix ${ }^{\mathrm{a}}$ & 0.25 \\
\hline \multicolumn{2}{|l|}{ Analyzed values, \% } \\
\hline Metabolisable Energy, Kcal/kg & 2919.69 \\
\hline Dry matter & 89.00 \\
\hline Crude Protein & 20.60 \\
\hline Ether Extract & 7.94 \\
\hline Ash & 10.84 \\
\hline Calcium & 2.53 \\
\hline Total Phosphorus & 0.60 \\
\hline Available Phosphorus ${ }^{c}$ & 3.55 \\
\hline \multicolumn{2}{|c|}{$\begin{array}{l}\text { a Provides per kg diet: } \alpha \text {-tocopherol acetate } 20 \mathrm{mg} \text {, retinol } 2.4 \\
\text { mg, cholecalciferol } 0.075 \mathrm{mg} \text {, riboflavin } 3 \mathrm{mg} \text {, thiamin } 3 \mathrm{mg} \text {, } \\
\text { pyridoxal } 3.5 \mathrm{mg} \text {, niacin } 20 \mathrm{mg} \text {, cyanocobalamin } 0.01 \mathrm{mg} \text {, folic } \\
\text { acid } 1 \mathrm{mg} \text {, biotin } 0.03 \mathrm{mg} \text {, pantothenic acid } 4 \mathrm{mg} \text {, choline } 600 \\
\mathrm{mg}, \mathrm{Fe} 60 \mathrm{mg}, \mathrm{Cu} 5 \mathrm{mg}, \mathrm{Zn} 60 \mathrm{mg}, \mathrm{Mn} 80 \mathrm{mg} \text {, I } 1 \text {, Se } 0.15 \mathrm{mg} \text {, } \\
\text { Co } 0.2 \mathrm{mg} . . \\
{ }^{\mathrm{b}} \text { Carpenter and Clegg equation (35) was used to calculate the } \\
\text { ME level. } \\
\text { c Calculated value. }\end{array}$} \\
\hline
\end{tabular}


Table 4. Effects of rosemary VO supplementation on the performance parameters ${ }^{1}$ of laying quails from 1 to 56 days of age.

\begin{tabular}{|c|c|c|c|c|c|c|c|c|c|c|}
\hline \multirow[b]{2}{*}{ Rosemary VO (mg/kg) } & \multicolumn{3}{|c|}{ Control } & \multicolumn{3}{|c|}{ Group 1} & \multicolumn{3}{|c|}{ Group 2} & \multirow[t]{2}{*}{$\mathbf{P}$} \\
\hline & \multicolumn{3}{|c|}{0} & \multicolumn{3}{|c|}{200} & \multicolumn{3}{|c|}{400} & \\
\hline Feed intake, g/d & 34.31 & \pm & 1.04 & 36.96 & \pm & 1.94 & 37.63 & \pm & 0.17 & NS \\
\hline Egg production, $\%$ & 73.47 & \pm & $2.60^{b}$ & 83.98 & \pm & $1.96^{\mathrm{a}}$ & 82.19 & \pm & $1.93^{\mathrm{a}}$ & $<0.01$ \\
\hline Egg weight, g & 11.00 & \pm & 0.10 & 11.11 & \pm & 0.09 & 11.60 & \pm & 0.10 & NS \\
\hline Feed efficiency, $\mathrm{kg}$ feed/kg egg & 4.35 & \pm & 0.21 & 4.05 & \pm & 0.14 & 4.02 & \pm & 0.13 & NS \\
\hline $\begin{array}{l}\text { Feed efficiency, } \\
\text { kg feed/ a dozen eggs }\end{array}$ & 0.58 & \pm & 0.03 & 0.54 & \pm & 0.02 & 0.56 & \pm & 0.01 & NS \\
\hline
\end{tabular}

a, b: Different letters within the same row indicate significant differences among the groups.

NS: Not significant $(P>0.05)$.

${ }^{1}$ Egg weight refers to the average of all eggs collected from 5 replicates. Values of egg production, feed intake and feed efficiency measured on the basis of group are means of 5 replicates, $n=5$.

exterior (shape index, eggshell thickness, breaking strength) and interior (haugh unit, egg yolk colour) egg quality parameters. No difference was determined in the 1st day egg yolk MDA values of the eggs obtained from the control and treatment groups and stored in a refrigerator at $+4{ }^{\circ} \mathrm{C}$. However, a significant decrease in MDA levels in egg yolk was observed on the $7^{\text {th }}(\mathrm{P}$ $<0.001)$ and $28^{\text {th }}(\mathrm{P}<0.01)$ days in storage with both doses of rosemary VO.

\section{Discussion and Conclusion}

The main active phenolic compounds of rosemary VO supplemented to quail feeds in this study were 1,8cineol (43.96\%), $\alpha$-pinene (25.33\%), camphene (11.09 $\%)$ and 3 -carene $(10,7 \%)$, respectively. Barakat and Ghazal (6) and, Santana-Méridas et al. (50) stated that carnosic acid, carnosol, camphene, caffeic acid, ursolic acid, rosmarinic acid, 1,8-cineole, $\alpha$ pinene are the most active antioxidant components found in rosemary VO. However, the VO composition of aromatic herbs may vary depending on the seasons, soil structure and climate factors.

In this study, dietary rosemary VO significantly increased egg production of laying quails (83.98 and 82.19 vs $73.47, \mathrm{P}<0.01$ ), but did not affect egg weight, feed intake and feed efficiency parameters (Table 4). There are contradictory results about the effect of dietary herbal extracts on performance parameters of broiler, laying hen and quails. While some researchers reported that herbal extracts positively affect performance parameters such as body weight gain, egg production, feed intake and feed efficiency $(7,27,58)$, the others stated that they had no significant effect on these parameters $(11,32,37,52)$. Yesilbag et al. (59) investigated the effects of rosemary VO $(200 \mathrm{mg} / \mathrm{kg})$, oregano $\mathrm{VO}(200 \mathrm{mg} / \mathrm{kg})$ and their mixtures $(40 \mathrm{mg} / \mathrm{kg}$ rosemary $\mathrm{VO}+160 \mathrm{mg} / \mathrm{kg}$ oregano $\mathrm{VO})$ on performance and egg quality parameters in laying quails. The authors reported that there was no significant difference between the groups in body weight and egg weight. However, they determined that the rosemary VO significantly improved egg production and feed efficiency, while the mixtures of volatile oils caused a significant increase in feed intake. Simsek et al. (53) investigated the effects of dietary rosemary VO (200 $\mathrm{mg} / \mathrm{kg})$, cinnamon VO $(200 \mathrm{mg} / \mathrm{kg})$ and a mixture of these volatile oils $(100 \mathrm{mg} / \mathrm{kg}$ rosemary $\mathrm{VO}+100 \mathrm{mg} / \mathrm{kg}$ cinnamon VO) on quails. At the end of the study, there was no difference between the groups in feed intake. While the highest egg weight was obtained from the rosemary VO group, the highest egg production and feed efficiency belonged to the cinnamon VO group. In a study conducted by Hernandez et al. (29) to determine the effect of two herbal extract mixtures $(5000 \mathrm{mg} / \mathrm{kg}$ sage + thyme + rosemary and $200 \mathrm{mg} / \mathrm{kg}$ oregano + cinnamon + pepper) on broiler performance, a little performance enhancer effect of herbal extract mixtures as in this study was seen, but none of the supplementations caused significant effects. Jamroz and Kamel (30), and Jang et al. (31) reported that herbal extracts or their volatile oils caused an increase in broiler performance by stimulating the secretion of digestive enzymes and increasing the digestibility of nutrients in feed. It has been suggested that the inconsistency in the effectiveness of herbal extracts on the performance of different poultry species may depend on many factors such as the composition of the basal diet, feed intake and environmental conditions or harvesting time of the herbs, extraction methods, conservation conditions and the differences in the levels of extracts supplemented to the diets $(12,16,28,40)$.

No significant effect of rosemary essential oil on eggshell breaking strength, eggshell thickness, shape index, haugh unit and egg yolk colour were determined in groups fed diets containing rosemary VO at levels of 200 $\mathrm{mg} / \mathrm{kg}$ and $400 \mathrm{mg} / \mathrm{kg}$ (Table 5). Similarly, rosemary VO supplementation to the laying hen diets did not have any significant effects on shape index, eggshell weight, 
eggshell thickness, eggshell breaking strength, haugh unit and yolk colour $(9,23,47)$. On the other hand, Cufadar et al. (17) stated that the eggshell breaking strength and eggshell thickness significantly increased in laying hens fed with $250 \mathrm{mg} / \mathrm{kg}$ rosemary VO supplemented diet when compared to the control group. Alagawany and Abd ElHack (2) also demonstrated that performance and egg quality parameters were improved by supplementation of $3000 \mathrm{mg} / \mathrm{kg}$ rosemary powder to laying hen diets. The number of studies examining the effects of rosemary VO on egg quality parameters in quails is limited. In a study conducted on laying quails, it was determined that rosemary VO significantly increased the egg white and yolk index values and affected the egg yolk colour positively (59). In a word, the supplementation of rosemary $\mathrm{VO}$ at different levels to the laying quail diets in the current study did not significantly affect the egg quality parameters.

The effect of rosemary $\mathrm{VO}$ on lipid oxidation of egg yolk stored in the refrigerator $\left(+4^{\circ} \mathrm{C}\right)$ for 1,7 and 28 days was determined by measuring the MDA level which is secondary oxidation product according to the TBA method. As the degree of oxidation in yolk lipids increases during eggs storage, the level of MDA measured in egg yolk also increases. There was no difference in the 1st day egg yolk MDA (TBA-reagent) values of the eggs obtained from control and treatment groups and stored in a refrigerator at $+4{ }^{\circ} \mathrm{C}$ in the present study. However, a significant decrease was determined in MDA levels of egg yolk in both levels of rosemary VO (200 and $400 \mathrm{mg} / \mathrm{kg}$ diet $)$ on the $7(0.05$ and 0.07 vs $0.44, \mathrm{P}<0.001)$ and 28
(2.97 and 3.03 vs 6.59, $\mathrm{P}<0.01$ ) days of storage (Table 6). Our data are in agreement with previous results reported on the antioxidant effect of rosemary VO. Radwan et al. (47) propounded that the supplementation of $1 \%$ rosemary VO to the diet of hens significantly reduced MDA values in eggs stored at room temperature compared to the control diet. Lopez-Bote et al. (38) and Tang et al. (56) also found that the dietary rosemary VO had the potential to increase the antioxidant capacity of chicken meat. It is well known that major phenolic compounds, carnosic acid, carnosol, camphene, caffeic acid, ursolic acid, rosmarinic acid, 1,8-cineole, $\alpha$ pinene and other phenolic compounds are the most active antioxidant components found in rosemary VO $(3,6,50)$. Galobart et al. (25) reported that there was a delay in iron-induced lipid oxidation in hen eggs fed on diets containing rosemary extract, and carnosic acid in rosemary could act as an effective antioxidant when included in the diet at levels of $500 \mathrm{mg} / \mathrm{kg}$ or above. Krause and Ternes (36) established that if the hen diets contain 500 or $1000 \mathrm{mg} / \mathrm{kg}$ of carnosic acid, the rate of carnosic acid transfer from diet to egg is $0.0025 \%$. It was determined that the rosemary VO used in the present study contains 1,8-cineol (43.96 $\%$ ), $\alpha$-pinene $(25.33 \%)$, campfene $(11.09 \%)$ and 3 carene (10.7\%) (Table 1), among the main phenolic compounds in rosemary mentioned above. In this study, the significant decrease in MDA levels of egg yolk stored in the refrigerator can be explained by the fact that phenolic hydroxyl groups in rosemary VO delay the formation of hydroxyl peroxide by giving hydrogen to peroxide radicals at the beginning of lipid oxidation $(19,20)$.

Table 5. Effects of rosemary VO supplementation on egg quality parameters ${ }^{1}$ of laying quails.

\begin{tabular}{|c|c|c|c|c|c|c|c|c|c|c|}
\hline \multirow[b]{2}{*}{ Rosemary VO (mg/Kg) } & \multicolumn{3}{|c|}{ Control } & \multicolumn{3}{|c|}{ Group 1} & \multicolumn{3}{|c|}{ Group 2} & \multirow[t]{2}{*}{$\mathbf{P}$} \\
\hline & & 0 & & & 200 & & & 400 & & \\
\hline Shape index & 77.28 & \pm & 0.29 & 77.72 & \pm & 0.24 & 76.22 & \pm & 0.56 & NS \\
\hline Eggshell thickness, $\mu \mathrm{m}$ & 0.13 & \pm & 0.00 & 0.14 & \pm & 0.00 & 0.14 & \pm & 0.00 & NS \\
\hline Eggshell breaking strength, N/cm2 & 13.17 & \pm & 0.23 & 13.05 & \pm & 0.24 & 13.11 & \pm & 0.29 & NS \\
\hline Haugh unit & 90.62 & \pm & 0.54 & 90.12 & \pm & 0.60 & 89.77 & \pm & 0.53 & NS \\
\hline Yolk color & 11.72 & \pm & 0.06 & 11.65 & \pm & 0.06 & 11.80 & \pm & 0.06 & NS \\
\hline
\end{tabular}

NS: Not significant $(\mathrm{P}>0.05)$.

${ }^{1}$ Values are means of 15 eggs ( 3 eggs per replicates), $n=15$.

Table 6. Effects of rosemary VO supplementation on MDA levels1 (mg MDA/kg sample) in egg yolk samples at different storage time $\left(+4{ }^{\circ} \mathrm{C}\right)$.

\begin{tabular}{|c|c|c|c|c|c|c|c|c|c|c|}
\hline \multirow[b]{2}{*}{ Rosemary VO (mg/kg) } & \multicolumn{3}{|c|}{ Control } & \multicolumn{3}{|c|}{ Group 1} & \multicolumn{3}{|c|}{ Group 2} & \multirow[t]{2}{*}{$\mathbf{P}$} \\
\hline & \multicolumn{3}{|c|}{0} & \multicolumn{3}{|c|}{200} & \multicolumn{3}{|c|}{400} & \\
\hline Day 1 & 0.05 & \pm & 0.01 & 0.04 & \pm & 0.01 & 0.03 & \pm & 0.01 & NS \\
\hline Day 7 & 0.44 & \pm & $0.10^{\mathrm{a}}$ & 0.05 & \pm & $0.01 b$ & 0.07 & \pm & $0.01^{\mathrm{b}}$ & $<0.001$ \\
\hline Day 28 & 6.59 & \pm & $0.52^{\mathrm{a}}$ & 2.97 & \pm & $0.52 b$ & 3.03 & \pm & $1.00^{\mathrm{b}}$ & $<0.01$ \\
\hline
\end{tabular}

a, b: Different letters within the same row indicate significant differences among the groups.

NS: Not significant $(\mathrm{P}>0.05)$.

1 Values are means of 15 eggs ( 3 eggs per replicates), $n=15$. 
In conclusion, supplementation of $200 \mathrm{mg} / \mathrm{kg}$ and $400 \mathrm{mg} / \mathrm{kg}$ of rosemary VO to the laying quail diets increased egg production without adversely affecting other performance parameters and egg quality, and reduced egg yolk MDA values during storage in the refrigerator. Based on the data obtained from this research and the information provided from the literature, it has been concluded that rosemary VO can be used as a natural antioxidant in laying quail diets to extend eggs shelf life and to minimize quality losses during storage, considering its strong antioxidant effect.

\section{Financial Support}

This research received no grant from any funding agency or sector.

\section{Ethical Statement}

This study was approved by the Uludag University Animal Experiments Local Ethics Committee (Decision no. 2018-15/04).

\section{Conflict of Interest}

The authors are declared that there is no conflict of interest.

\section{References}

1. Acamovic T, Brooker JD (2005): Biochemistry of plant metabolites and their effects in animals. Proc Nutr Soc, 64, 403-412.

2. Alagawany M, Abd El-Hack ME (2015): The effect of rosemary herb as a dietary supplement on performance, egg quality, serum biochemical parameters, and oxidative status in laying hens. J Anim Feed Sci, 24, 41-347.

3. Al-Sereiti MR, Abu-Amer KM, Sen P (1999): Pharmacology of rosemary (Rosmarinus officinalis) and its therapeutic potentials. Indian J Exp Biol, 37, 124-30.

4. AOAC (2000): Association of Official Analytical Chemists, Official Methods of Analysis, 17th ed. AOAC International Maryland USA.

5. Balnevea, D, Muheereaza SK (1997): Improving eggshell quality at high temperatures with dietary sodium bicarbonate. Poult Sci, 76, 588-593.

6. Barakat H, Ghazal IG (2016): Antifungal and antioxidant activities of Rosemary (Rosmarinus officinalis L.) essential oil. J Food Dairy Sci Mansoura Univ, 7, 273-282.

7. Basmacioglu H, Tokusoglu O, Ergül M (2004): The effect of oregano and rosemary essential oils or alphatocopheryl acetate on performance and lipid oxidation of meat enriched with n-3 PUFA's in broilers. S Afr J Anim Sci, 34, 197-210.

8. Bishop CD (1995): Antiviral activity of the essential oil of Melaleuca alternifolia (Maiden and Betche) Cheel (tea tree) against tobacco mosaic virus. J Essential Oil Res, 7, 641644.

9. Botsoglou N, Florou-Paneri P, Botsoglou E, et al (2005): The effect of feeding rosemary, oregano, saffron and $\alpha^{\prime \prime}$ - tocopheryl acetate on hen performance and oxidative stability of eggs. S Afr J Anim Sci, 35,143-151.

10. Botsoglou NA, Christaki E, Florou-Paneri P, et al (2004): The effect of a mixture of herbal essential oils or tocopheryl acetate on performance parameters and oxidation of body lipid in broilers. S Afr J Anim Sci, 34, 5261.

11. Botsoglou NA, Florou-Paneri P, Christaki E, et al (2002): Effect of dietary oregano essential oil on performance of chickens and on iron-induced lipid oxidation of breast, thigh and abdominal fat tissues. $\mathrm{Br}$ Poult Sci, 43, 223-230.

12. Brenes A, Roura E (2010): Essential oils in poultry nutrition. Main effects and mode of action. Anim Feed Sci Technol, 158, 1-14.

13. Card LE, Nesheim MC (1972): Poultry Production, 11th ed (Philadelphia, PA, Lea and Febiger).

14. Carpenter KJ, Clegg KM (1956): The metabolizable energy of poultry feeding stuffs in relation to their chemical composition. J Sci Food Agr, 7, 45-51.

15. Chao SC, Young DG, Oberg CJ (2000): Screening for inhibitory activity of essential oils on selected bacteria, fungi and viruses. J Essential Oil Res, 12, 639-649.

16. Cosentino S, Tuberoso CIG, Pisano B, et al (1999). In vitro antimicrobial activity and chemical composition of Sardinian Thymus essential oils. Lett Appl Microbiol, 29, 130-135.

17. Cufadar Y (2018): Effects of dietary different levels of rosemary essential oil on performance and eggshell quality parameters in laying hens. Selcuk J Agr Food Sci, 32, 454457.

18. Dorman HJD, Deans SG (2000): Antimicrobial agents from plants: antibacterial activity of plant volatile oils. $\mathrm{J}$ Appl Microbiol, 88, 308-316.

19. Estévez M, Ramírez R, Ventanas S, et al (2007): Sage and rosemary essential oils versus BHT for the inhibition of lipid oxidative reactions in liver pâté. LWT, 40, 58-65.

20. Farag RS, Daw ZY, Hewedi FM, et al (1989): Antimicrobial activity of some Egyptian spice essential oils. J Food Prot, 5, 665-667.

21. Farese G, Schmidt JL, Mager M (1967): An automated method for the determination of serum calcium with glyoxal bis (2-hydroxyanil). Clinical Chem, 13, 515-520.

22. Florou-Paneri P, Palatos G, Govaris A, et al (2005): Oregano herb versus oregano essential oil as feed supplements to increase the oxidative stability of turkey meat. Int J Poult Sci, 11, 866-871.

23. Florou-Paneri P, Dotas D, Mitsopoulos I, et al (2006): Effect of feeding rosemary and $\alpha$-tocopheryl acetate on hen performance and egg quality. J Poultry Sci, 43, 143-149.

24. Gachkar L, Yadegari D, Rezaei MB, et al (2007): Chemical and biological characteristics of Cuminum cyminum and Rosmarinus officinalis essential oils. Food Chem, 102, 898-904.

25. Galobart J, Barroeta AC, Baucells MD, et al (2001): Effect of dietary supplementation with rosemary extract and $\alpha$-tocopheryl acetate on lipid oxidation in eggs enriched with $\omega 3$-fatty acids. Poultry Sci, 8, 460-467.

26. Gericke S, Kurmies B (1952): Die kolorimetrische Phosphorsäurebestimmung mit der Ammonium-Vandat- 
Methode und ihre Anwendung in der Pflanzenanalyse. $\mathrm{Z}$ Pflanzenernähr Düng Bodenk, 59, 235-247.

27. Hajiazizi F, Torki M, Habibian M (2016): Effects of rosemary essential oil and zinc on performance, egg quality traits, and some serum metabolites in laying hens. $\mathrm{J}$ Livestock Sci and Technol, 4, 01-06.

28. Hashemi SR, Davoodi H (2011): Herbal plants and their derivatives as growth and health promoters in animal nutrition. Vet Res Commun, 35, 169-180.

29. Hernández F, Madrid, J, Garcia V, et al (2004): Influence of two plant extracts on broiler performance, digestibility, and digestive organ size. Poult Sci, 83, 169-174.

30. Jamroz D, Kamel C (2002): Plant extracts enhance broiler performance. in non-ruminant nutrition: antimicrobial agents and plant extracts on immunity, health and performance. J Anim Sci, 80, 41-46.

31. Jang IS, Ko HY, Ha JS, et al (2004): Influence of essential oil components on growth performance and the functional activity of the pancreas and small intestine in broiler chickens. Asian-Australasian J Anim Sci, 17, 394-400.

32. Jang IS, Ko YH, Kang SY, et al (2007): Effect of commercial essential oils on growth performance, digestive enzyme activity and intestinal microflora population in broiler chickens. Anim Feed Sci Technol, 134, 304-315.

33. Jayashree T, Subramanyam C (1999): Anti-aflatoxigenic activity of eugenol is due to inhibition of lipid peroxidation. Lett Appl Microbiol, 28,179-183.

34. Ke PJ, Ackman PJ, Linke BH, et al (1977): Differential lipid oxidation in various parts of frozen mackerel. J Food Technol, 12, 37-47.

35. Kempaiah RK, Srinivasan K (2002): Integrity of erythrocytes of hypercholesterelomic rats during spices treatment. Mol Cell Biochem, 236, 155-161.

36. Krause EL, Ternes W (2000): Bioavailability of the antioxidative Rosmarinus officinalis compound carnosic acid in eggs. Eur Food Res Techno, 3, 161-164

37. Lee KW, Everts H, Kappert HJ, et al (2003): Effects of dietary essential oil components on growth performance, digestive enzymes and lipid metabolism in female broiler chickens. Br Poult Sci, 44, 450-457.

38. Lopez-Bote CJ, Gray JI, Gomaa EA, et al (1998): Effect of dietary administration of oil extracts from rosemary and sage on lipid oxidation in broiler meat. Br Poult Sci, 39, 235-240.

39. Mari M, Bertolini P, Pratella GC (2003): Nonconventional methods for the control of post-harvest pear diseases. J Appl Microbiol, 94, 761-766.

40. Marino M, Bersani C, Comi G (1999): Antimicrobial activity of the essential oils of Thymus vulgaris L. measured using a bioimpedometric method. J Food Protect, 62, 10171023.

41. Mourey A, Canillac N (2002): Anti-Listeria monocytogenes activity of essential oils components of conifers. Food Control 13, 289-292.

42. NRC (1994): National Research Council, Nutrient Requirements of Poultry, 9th Ed. National Academy Press, Washington, DC.

43. Palá-Paúl J, García-Jiménez R, Pérez-Alonso MJ, et al (2004): Essential oil composition of the leaves and stems of Meum athamanticum Jacq. from Spain. J Chromatogr A, 1036, 245-247.
44. Pandey R, Kalra A, Tandon S, et al (2000): Essential oil compounds as potent source of nematicidal compounds. $\mathbf{J}$ Phytopathol, 148, 501-502.

45. Pessoa LM, Morais SM, Bevilaqua CML, et al (2002): Anthelmintic activity of essential oil of Ocimum gratissimum Linn. and eugenol against Haemonchus contortus. Vet Parasitol, 109, 59-63.

46. Platel K, Srinivasan K (2004): Digestive stimulant action of spices: A myth or reality? Indian J Med Res, 119, 167179.

47. Radwan NL, Hassan RA, Qota EM, et al (2008): Effect of natural antioxidant on oxidative stability of eggs and productive and reproductive performance of laying hens. Int J Poult Sci, 7, 134-150.

48. Richheimer SL, Bernart MW, King GA, et al (1996): Antioxidant activity of lipid-soluble phenolic diterpenes from rosemary. J AOCS, 73, 507-514.

49. Rota C, Carraminana JJ, Burillo J, et al (2004): In vitro antimicrobial activity of essential oils from aromatic plants against selected foodborne pathogens. J Food Prot, 67, 1252-1256.

50. Santana-Méridas O, Polissiou M, Izquierdo-Melero ME, et al (2014): Polyphenol composition, antioxidant and bioplaguicide activities of the solid residue from hydrodistillation of Rosmarinus officinalis L. Ind Crop Prod, 59, 125-134.

51. Scheeder, MRL (2000): Internal research report. Institute of Animal Science. Nutritionbiologie. ETH-Zürich, Switzerland.

52. Shanmugavelu S, Acamovic T, Cowieson AJ (2004): Effect of thyme oil and garlic powder on the nutritive value of soybean meal. Br Poult Sci, 45, 54-55.

53. Simsek UG, Ciftci M, Özcelik M, et al (2015). Effects of cinnamon and rosemary oils on egg production, egg quality, hatchability traits and blood serum mineral contents in laying quails (Coturnix coturnix Japonica). Ankara Univ Vet Fak Derg, 62, 229236.

54. Srinivasan K (2004): Spices as influencers of body metabolism: an overview of three decades of research. Food Res Int, 38, 77-86.

55. Sümbüloglu K, Sümbüloglu V (1995): Biyoistatistik. Özdemir Yayıncılık, 6. Baskı, Ankara.

56. Tang SZ, Kerry JP, Sheeham D, et al (2000): Dietary tea catechins and iron-induced lipid oxidation in chicken meat, liver and heart. Meat Sci, 56, 285-290.

57. Viuda-Martos M, Ruiz Navajas $Y$, Sánchez Zapata E, et al (2010): Antioxidant activity of essential oils of five spice plants widely used in a Mediterranean diet. Flavour Frag J, 25, 13-19.

58. Yesilbag D, Eren M, Agel H, et al (2011): Effects of dietary rosemary, rosemary volatile oil and vitamin $E$ on broiler performance, meat quality and serum SOD activity. Br Poult Sci, 52, 472-482.

59. Yesilbag, D, Gezen S, Biricik H, et al (2013): Effects of dietary rosemary and oregano volatile oil mixture on quail performance, egg traits and egg oxidative stability. Br Poult Sci, 54, 231-237.

60. Zaouali Y, Bouzaine T, Boussaid M (2010): Essential oils composition in two Rosmarinus officinalis $L$. varieties and incidence for antimicrobial and antioxidant activities. Food Chem Toxicol 48, 3144-3152. 